6

\title{
Qur'anic Values and Modernity in Contemporary Islamic Ethics
}

\author{
Taha Abderrahmane and Fazlur Rahman in Conversation
}

\author{
Ramon Harvey
}

\section{Introduction}

Islam, like other religions, looks back to an early sacred time, in which its primary scripture, the Qur'an, was given to the Prophet Muhammad who directly instructed the people in religious and ethical guidance. Believers are in no doubt about the importance of this founding moment for the development of the community. Yet, time does not stand still. As century upon century has passed, Muslims live far from the society initially transformed by revelation. A question that forces itself upon us is, in the words of Ebrahim Moosa: "How do the norms and values of revelation have an enduring relevance to religious communities without becoming anachronistic?" (Moosa 2000, 15). Thus, one of the compelling unresolved problems of our day is how to live at a remove from the time of revelation without a mere nostalgic re-enactment of the outward form of the religion, but also without abandoning it, or unthinkingly forcing it into the parameters of modernity.

Two major figures that have sought to provide theoretical frameworks to address this conundrum are the Moroccan philosopher Taha Abderrahmane (b. 1944) and the Pakistani émigré thinker Fazlur Rahman Malik (1919-1988). While each of them stakes out an original position, they are united by placing the category of the ethical at the centre of their thought, and by seeing its retrieval as the basis for a contemporary renewal of the Islamic tradition and its legal thought. These parallels between their projects lead naturally to the hypothesis that there is a great deal to gain by closely comparing their works on this key question, as well as major recent attempts to utilise their ideas.

Abderrahmane's scholarly career began with his entry into the Mohammed v University in Rabat to study philosophy, after an initial interest in poetry before the ${ }_{1967}$ Arab-Israeli war. He received further graduate degrees in philosophy from the Sorbonne in Paris, culminating with a doctorate in 1985. From the 1970s, Abderrahmane worked as a professor of logic and philosophy of lan- 
guage at Mohammed v University until his retirement in 2005. He remains a prolific author with a shift in recent decades to a focus on ethics and Islamic renewal. Abderrahmane has referred to his reconstructive intellectual project as the "Rabat School" (Hashas 2015, 71-74). The ethical and spiritual dimensions of his thought must also be viewed in the light of his membership of the Morocco-based Boutchichi Sufi țaríqa (order) (Mashrūh 20o9, 32-33). Despite Abderrahmane's knowledge and engagement with themes of logic, language and ethics within the Western philosophical tradition, his work has neither featured in major works on modern Islamic thought (Hashas 2015, 70), nor received engagement from major Western ethical thinkers with similar concerns (Bevers 2018, 78-79). He has been more celebrated in the Arabic-speaking world, especially within Morocco (Hashas 2015, 72). However, there is still a sense that his work has not received the attention it deserves within circles of contemporary Arabic philosophical thought, possibly due to its difficult linguistic and logical foundations (Bū Zabra 2011, 18).

In the case of Fazlur Rahman, an initial grounding in traditional Islamic education from his father in the Indian subcontinent was followed by the study of Arabic at Punjab University and a doctorate on Ibn Sinna (d. 428/1037) at the University of Oxford. His subsequent career was primarily based in the British, Canadian and American universities of Durham, McGill and Chicago. A formative interlude in his academic career was a stint at the head of the Central Institute of Islamic Research in Karachi during the 196os before being forced to leave the country due to opposition from traditional ulema to his theology of revelation (El-Affendi 2009, 32). His experience in Pakistan coincides with a shift in his thought from studying the history of Islamic philosophy to increasingly focus on the Qur'an and core ethical message of Islam, the Muslim tradition as a means for its transmission through history, and the prospects for reviving it in the modern world (Moosa 2000, 23). Fazlur Rahman's ideas have been very influential in Western academia, in Turkey and to some extent in Indonesia, with less influence in the Arab world and the Indian subcontinent (Koç 2012, 16-17; El-Affendi 2009, 32-33).

I have divided this chapter into two main sections. In the first I will discuss the approaches of Taha Abderrahmane and Fazlur Rahman to reading ethical values within the Quran. I will argue that while both focus on the relevance of the Qur'an's context in order to uncover extrahistorical ethical values, their thought differs markedly in emphasis. Abderrahmane concentrates on a theoretical account of Sufi virtue ethics, which allows him to make targeted modifications to the classical theory of maquassid al-sharîa, or the purposes of legislation. The ideas of Fazlur Rahman challenge this approach by stressing the development of a genuine theory of social ethics from the Quran able to 
deal with legal reform for the benefit of the community. Fazlur Rahman's work also shows a proclivity for thinking about hermeneutics, which he illustrates with applied examples.

The second section will turn to the two thinkers' application of Qur'anic ethics to the contemporary world. Again, while their overall project of the centrality of the ethical in modernity is shared, each has particular characteristics that open up new avenues for thought. Yet, both betray points of potential critique. In the case of Abderrahmane, his ideas challenge the Western hegemony of modernity, and seek to articulate an alternative conception in which Quranic values can be ethically relevant. Fazlur Rahman is more appreciative of modernity and enlightenment universal reason, and sees the potential for Muslims to generate a beneficial synthesis between them and the timeless ultimate values of revelation. I will also discuss in this section some of the major figures who have received and developed each of the two scholars' bodies of work, before concluding with the prospects that lie ahead for the coming century of Islamic ethics.

\section{Seeking Qur’anic Values}

Both Taha Abderrahmane and Fazlur Rahman hold that the renewal of the Islamic tradition within modernity can only be sought through a discourse of ethics. More precisely, permanent ethical values must be sought within the primary document of revelation, the Qur'an. It is in the theoretical explication of how this may be done that their thought can be contrasted and their relationship to debates of ethics, hermeneutics and the Islamic tradition can be assessed.

Abderrahmane proposes that religious dispensations begin in a natural, or fitrī, state and then enter into a time-affected, or waqtī, state. The accretions of history that lead to such a deviation from the original ethical nature of the religion may occur at a slower or quicker rate, depending on various factors. Moreover, the waqtī and fitri states may be closer or further apart due to the historical accidents suffered by various religions ('Abd al-Raḥmān 2014a, 102). Eventually, each dispensation is abrogated by the one following it. Abderrahmane refers to each religion as having two eras, an ethical and a historical one. He defines the ethical era as "the period of time between its revelation until it is superseded by the revelation of a new religion", and the historical era as "the period of time between its revelation and the time it is brought to an end by people who no longer believe in it" (Abderrahmane 2008a, 16). As Islamby which Abderrahmane here means the religious dispensation brought spe- 
cifically by the Prophet Muhammad - is the final revealed religion, it is the only one whose ethical and historical eras are one and the same. Nevertheless, while Abderrahmane believes that Islam is the only contender for a religious dispensation still in its ethical phase, it has undergone historical corruption, such that it needs renewal in order to return to its fițī state ('Abd al-Rahmmān 2014a, 102). This requires "rooting ethics" (tarsīkh al-akhläq) in the values of revelation, as appreciated through their initial historical setting ('Abd al-Raḥmān 2006, 202).

Abderrahmane is intensely critical of what he sees as a modern historicist approach to scripture that attempts to desacralise the Qur'an and cut off its link with the divine (Hashas 2019, 188). He makes a number of criticisms of the methodology followed by those he calls "modern conformist readers" (ahl al-qirä’a al-hadäthiyya al-muqallida): they seek to deny that the Qur'an came with established eternal rulings ( $a$ hkäm), which would be a hindrance to their agenda, and claim instead that they are merely contingent upon particular historical circumstances ('Abd al-Raḥmān 2006, 184); they go beyond the limits established by jurists and exegetes in interpreting Qur'anic rulings ('Abd alRaḥmān 2006, 185); and they apply historical criticism to issues of belief and worship, and not simply to transactional and penal matters ('Abd al-Raḥmān 2006, 186).

For Abderrahmane, the Qur'an cannot be relegated to a past historical era, because as the final revelation, it is foundational to every time that follows it. The verses containing rulings have both a legal (qūnūnī) and ethical (akhlāqū) dimension. These ethics are not merely for the perfection of actions but are essential for the human being and are the reason for the Prophet Muhammad's mission (Abderrahmane 2006, 203). In fact, Abderrahmane makes a break from the Aristotelian philosophical heritage by asserting that the core feature distinguishing human beings from animals is their ethical rather than rational ('aqlāniyya) nature ('Abd al-Raḥmān 200o, 13-14). He conceptualises ethical values (qiyam akhläqiyya) as extrahistorical: they can "affect time but are not affected by time" ('Abd al-Raḥmān 2006, 204); he defines "value" as follows:

Value is an abstract meaning that Man holds in his heart but cannot grasp with his senses. Yet, and despite this abstraction, this meaning is what guides him in his life and enhances his humanity. In fewer words, values are innate and lofty meanings that guide Man to righteousness.

ABDERRAHMANE 2O14b, 111

Preservation of such ethical values within the context of modernity is key to Abderrahmane's programme of renewal and this can only be done by link- 
ing the values to the contextual atmosphere (wașl al-zarfí wa-l-siyāqu) of the Qur’anic verses ('Abd al-Raḥmān 2006, 203).

Moosa provides an insightful analysis of how Abderrahmane's concept of value intersects with his efforts to reinterpret al-Shātibī's (d. 790/1388) theory of maqāssid al-sharîa. Abderrahmane sees this legal theory as insufficiently ethically grounded and seeks to rectify this by building on the idea of alJuwaynī (d. 478/1085) that the word maqșad (purpose) has different conceptual registers that can be pegged to different moral aspects of human action. Thus, while maqșad can refer to an outcome, in the sense of the action $\left(f^{i} l\right)$ itself, it can also refer to its intention (niyya) and to its end, or value (qima) (Moosa 2014, 183). The overall picture is teleological, for though each action is preceded by an intention, it has as its end a distinct value ('Abd al-Rahmān 2015, 87; Moosa 2014, 184-185). Furthermore, these internal ethical categories correspond to three external legal ones: intention, action and value correspond to cause ('illa), legal action (qadiyya) and legal rule (jiha) respectively ('Abd al-Raḥmān 2015, 88). Abderrahmane's definition of value within the framework of virtue ethics leads him to redesign its typology for the theory of maqāșid al-sharía. Although the traditional five necessities (darüriyyāt) of maqāṣid theory—religion, life, reason, family and property_appear as values of beneficence (mașālih) and malevolence (mafāsid), a classification redolent of 'Izz al-Dīn b. 'Abd al-Salām (d. 66o/1262), Abderrahmane prioritises spiritual values, then rational values, followed by life values (Abderrahmane 2015, 86; Moosa 2014, 185-186).

Abderrahmane's project within legal theory can be seen as an effort to give Aristotelian and Sufi virtue ethics, as understood through his own philosophy of the trusteeship paradigm (al-itimanniyya), a regulative function in the law. It is also interesting to see this move through a longer historical lens. The concepts from which he draws inspiration have a rich history in the Muslim intellectual tradition, in the field of Sufism through figures such as al-Muhāsibì (d. 243/857), al-Rāghib al-Iṣfahānī (d. 422/1031) and al-Ghazālī (d. 505/1111), rather than in legal theory. Abderrahmane's entry into the discourse of the legal tradition seems to be a strategic choice based on his diagnosis of the malady of outward law dominating ethics in Muslim thought ('Abd al-Raḥmān 2015, 90). This, in turn, arguably, reflects his analysis of modernity in the Islamic world replicating the West in making morality follow, rather than lead, materiality (Bevers 2018, 164).

The intervention in ethical theory proposed by Abderrahmane remains at the level of metaethics and normative ethics and does not provide many details of how, in practice, specific moral principles would be extracted from the Qur'an (Moosa 2014, 187). Abderrahmane's emphasis on adding Sufi virtue ethics to legal theory leaves it unclear whether he has given much consideration 
to applied social ethics that could be derived from the Qur'an beyond the very general categories found within the maqūṣid al-sharîa literature. As noted by Monir Birouk, the focus on individual ethics and piety in Abderrahmane's work at the expense of social ethics and the discourse of justice may undermine his broader project (Birouk 2017).

A focus on the social aspect of the Qur'an's ethical message is one of the distinguishing features of Fazlur Rahman's oeuvre. He takes issue with what he sees as the grafting of the Sufi system of spiritual purification onto the legal tradition, which he thinks replaces a genuine moral philosophy that could direct reform of the law in the public sphere (Rahman 1971, 94). The point of departure for Fazlur Rahman's contribution to contemporary Islamic ethics is, instead, the assertion that central to the Prophet Muhammad's religious mission was the moral development of human society in its communal dimension (Rahman 1982, 5). However, he shares with Abderrahmane the aim of retrieving objective moral values from the Qur'an, highlighting the difference between the historical and the normative in Islam (Koshul 1994, 406). In his words:

All values that are properly moral —and it is these with which we shall be concerned - have also an extrahistorical, "transcendental" being, and their location at a point in history does not exhaust their practical impact or, one might even say, their meaning.

RAHMAN 1982, 5

These values can only be appreciated by their place within the unity of the Qur'an's Weltenschauung and thus require an integrated approach in order to be extracted from the divine response to the immediate socio-historical context of the revelation (Rahman 1970, 329; Rahman 1982, 2-3). Fazlur Rahman highlights the complexity of the Qur'an and the need to distinguish between its macro-background, which can be gleaned from a general knowledge of the conditions of society at the time of the Prophet Muhammad, and the specific situations surrounding the revelation of verses known as the asbāb al-nuzūl (Rahman 1980b, 241). He pays special attention to distinguishing between a Qur'anic ruling (hukm) and its ratio legis ('illat al-hukm), which is the purpose for its pronouncement (Rahman 198ob, 242). This leads him to criticise the commonly drawn distinction between 'illa as cause and hikma as purpose, in effect arguing for the determination of the hukm by its hikma (Rahman 1979, 219-221; cf. Harvey 2018, 41-42). His most significant methodological proposition is the development of what he terms a double movement theory. In the first step of the first movement, the purposes of the Quranic injunctions are 
considered in the light of their socio-historical contexts; in the second step, a coherent system of general ethical principles is extracted. The second movement actualises these ethics within the contemporary world (Rahman 1982, 6-7; Rahman 198ob, 244). Moosa argues that this embrace of historical analysis after his early focus on the work of Muslim philosophers represents a definitive turn away from comprehensive metaphysical systems to the interplay between revelation and history (Moosa 2000, 23). This is substantiated by Fazlur Rahman's declaration: " $[t]$ he theologians have been too much preoccupied with God and His nature; they have ignored the nature of man and his function" (Rahman 1971, 97).

Fazlur Rahman's reflection on the specifics of the interpretive task and its problematics, as well as his reference to prevailing twentieth-century debates within Western philosophy, means that his hermeneutics can be more easily determined than those of Taha Abderrahmane. Though he affirms that with the exception of fully detailed matters "all interpretations and approaches to truth are subjective" (Rahman 1970, 330), when it comes to the purposes of Qur'anic injunctions, he uses the hermeneutics of Emilio Betti (1890-1968) to argue that the divine intent can be objectively uncovered (Rahman 1982, 8). Betti, as described by Moosa, developed four canons to be used in the hermeneutic act, which would allow the interpreter to "reverse engineer" the original creative impulse of the author: first, to understand the author's point of view; second, to understand the unity of their thought; third, to retrace the creative process and inevitably add a degree of subjectivity; fourth, to reduce that subjectivity as much as is feasible (Moosa 2000, 18-19).

According to Felix Körner, Fazlur Rahman adjusts Betti's canons in two respects: considering the communication of the divine mind with reference to a specific historical situation as part of his first movement; and returning to the present day in order to apply the value in modernity, which is his addition of a second movement (Körner 2005, 115). Körner argues that Gadamer's (1900-2002) criticism of Betti's reconstructive approach as Romantic psychologism (see Gadamer 2013, 533) is cogent as he does not supply enough grounds to adequately determine the original intentions behind a text. However, Betti does provide a defined text-oriented method upon which Fazlur Rahman can build his own system (Körner 2005, 115). For his part, Fazlur Rahman is aware of the debate between Gadamer and Betti. Siding with the latter, he presents Gadamer's phenomenological approach as constraining the interpreter by the shackles of their historical consciousness. This, he thinks, leads to an interpretive subjectivism that cannot recover the objective meanings of a text and would thereby render meaningless his double movement theory (Rahman 1982, 9; see Bektovic 2016, 162-163). 
Arguably, Fazlur Rahman has misunderstood the nature and implications of Gadamer's position. Gadamer's acknowledgement that any interpreter is circumscribed to some extent by their own being and their relationship to the past does not predetermine how they will interpret a historical text (Körner 2005 , 118). Körner shows how the Gadamerian position is able to defend itself and land some blows against Fazlur Rahman's theory. Though Fazlur Rahman claims to be able to cut through the tradition to return to a holistic Qur'anic ethics, he asks the quintessential question of Muslim ethical thought, "how should we act?" Furthermore, though he argues that the law must have (a) purpose(s), he ultimately accepts whatever purpose he discovers in the Qur'an because it is the will of God, which makes Fazlur Rahman a "revelation-positivist" (Körner 2005, 119-120). Note that if Körner is right on this point, it would partially undermine Fazlur Rahman's own criticism of Ash'arī voluntarism (see Rahman $1982,3)$. Finally, Gadamer's idea that our interpretive vantage point on the past constantly shifts may challenge Fazlur Rahman's confidence in an objective method (see Gadamer 2013, 301-302), but does not make his project of Qur'anic ethical recovery impossible. Rather, he should recognise the requirement of the hermeneutic circle and the constant need to return to the object of interpretation in the light of new experiences (Körner 2005, 120; see Caputo 2018, 104-105).

Körner goes on to argue that Fazlur Rahman's search for an objective method to uncover God's designs for human beings in all time periods not only fits well with Betti's psychological hermeneutics but possibly also reflects a distinctively Qur'anic theology of revelation. He contrasts this with Gadamer's perspective which he sees as more suitable for the Biblical (Christian and Jewish) foregrounding of God's self-expression as the unfolding of events in history ahead of revealed communication (Körner 2005, 121). It is ironic that this point arises from critique of Fazlur Rahman, perhaps the most famous modern Muslim exponent of a participative, as opposed to a stenographic — or purely receptive - theology of revelation (Rahman 1976, 33; for this terminology, see Sommer 2015, 2).

Yet it does not seem at all clear that the authoritative communication of the Qur'an must be an ill fit with the philosophy of Gadamer. Körner's own study of the Turkish theologian Mehmet Paçaci shows that Gadamer's idea of constant interpretation can be synthesised with Fazlur Rahman's first movement (Körner 2005, 79; and see below). My recent book, The Qur'an and the Just Society, has shown how a key aspect of Fazlur Rahman's project, the search for specific values within the Qur'an, can be embedded in a natural law theological framework that is indebted to Gadamerian hermeneutics (Harvey 2018, 194). In my model, which constructively builds on the Māturīdī theological school, God 
reveals His wisdom both through His speech in the Qur'an and through His creative act within the progression of history, such that the human ethical agent must continually reconcile the two (Harvey $2018,36,41-42$ ). Overall, it would seem that the key consideration is the theological approach to God's acts of revelation and creation within any given tradition, rather than the inherent nature of the Biblical and Qur'anic dispensations.

How successful was Fazlur Rahman in applying his methods for extracting values from the Qur'an? He certainly did not attempt to carry this procedure out in any systematic way. Nonetheless, over the course of his career, he made many forays within individual thematic areas. While he had published a number of relevant articles before he made his double movement theory fully explicit, these earlier publications obviously provided him with some of the evidential groundwork to propose his more developed theoretical claims. Aspects of the Qur'anic discourse that Fazlur Rahman attempted to look at through an ethical lens include the following: slavery (Rahman 1963, 212-214), ribä (usury) (Rahman 1964), ḥudūd (limits; prescribed punishments) (Rahman 1965), family law (Rahman 1980a), shūrā (consultation) (Rahman 1981), ìmān (faith), islām (surrender to God), and taqwā (piety) (Rahman 1983). These discussions are insightful, yet often all too brief and do not provide the sustained holistic analysis required by his double movement theory.

\section{The Ethical in Modernity}

The two thinkers explored in this study devote a significant proportion of their intellectual labour to considering modernity and the conditions for successful Islamic ethics within it. Both argue that an appreciation of the effects of modernity on Muslim thought combined with profound ethical reflection on the Qur'an can lead to renewal. Nonetheless, there are some important differences in their analysis of modernity and their proposals for an ethical response to it.

Abderrahmane argues that the question of modernity is inseparable from that of ethics. He distinguishes between the mere "fact of modernity" (wāqic al-hadätha), understood as the current Western hegemonic reality, and the "spirit of modernity" (rüh al-hadätha), which represents general characteristics with the potential for alternative applications ('Abd al-Raḥmān 2006, 19; Hashas 2015, 85). While Western modernity is built upon the rejection of morality in the name of productivity (Abderrahmane 2008b, 89), an alternative modernity can be conceived, in which the basic ethical nature of the human being becomes the central fact and breaks the harmful domination over nature, 
society and the individual (Hashas $2015,85^{-86}$ ). Though largely framing his approach within his own tradition of Arab-Islamic philosophy, Abderrahmane promotes his conception of the spirit of modernity as one that is more open to the real diversity of the modern world than classical Western universals (Hashas 2015, 76, 86). He proposes, in the words of Michael Bevers, that, "Islam's answer to the question of ethics in the 21st century can contribute to the formation of a pluralist civilization of ethos worldwide" (Bevers 2018, 197).

Interestingly, in the light of the preceding discussion concerning Fazlur Rahman, the theoretical posture that Abderrahmane takes towards tradition has some similarities to that of Gadamer, whose Truth and Method he read in French translation (see 'Abd al-Rahmān 1995, 110-111). Abderrahmane argues that the connection with tradition is not a matter of choice that can be entered and left at will. If one does not work from one's own tradition, the only alternative is to draw from another. Furthermore, he explicitly states that it is impossible to cut all connections to the present, return to the past and live with its values like one's grandparents ('Abd al-Rahmmān 2011, 15-17). What Islam needs in modernity is to wipe away inappropriate historical accretions and return to the fitri ethical form of the religion.

Abderrahmane argues that the embedding of ethics requires removing each ossified rule that in the context of today harms foundational human values ('Abd al-Rahmmān 2006, 202). The reason for this is that a Qur'anic ruling may not realise the same value at a later period of history as it did at the time of revelation. What is required is a study of the Quranic verses within the context of the world today with a view to making their divine guidance relevant to the present and future ('Abd al-Rahmān 2006, 204). Mohammed Hashas explains this point: "the sealing of revelation then goes beyond the time of its appearance; each era becomes its possible age of realization. The historicity of revelation becomes "futuristic," and it should be always modern" (Hashas 2018, 190). Again, Abderrahmane's theoretical discussion outstrips his applied aspirations and he does not provide a clear sense of what his ideas would mean in practice. He mentions in passing that the ossified rulings to be abandoned include those concerning slavery and mutual interaction with pagans ('Abd alRaḥmān 2006, 203-204) —issues that have long been marginal to most Muslim societies - but prefers to remain on the level of theory, rather than its application.

One of the ironies of Abderrahmane's thought is his call for practice-based solutions through the medium of an extremely abstract theoretical discourse. Thus, he argues that the transformation from waqtī (time-affected) to fitri (natural) religion cannot be completed through theory which engages only with the thinking of its own time: 
Theory within the transmitted texts, as they are examined critically and comparatively, or explanatively and figuratively, or in terms of excavation and deconstruction is not what connects to the natural form of the religion. This is true even if it unveils part of its realities, because this theory is compelled to connect with the thinking and theorising that is appropriate to a time other than that of this religion.

'ABD AL-RAḤMĀN 2O14a, 1O2-103

His point is that theoretical insight is not enough on its own and must be completed with praxis, as the natural disposition can only be recovered with specific spiritual practices. This is how the human being can engage in trusteeship and connect to divine witnessing ('Abd al-Raḥmān 2014a, 103). Again, it seems that Abderrahmane places spiritual purification through the Sufi path at the heart of his conception of social ethics. It is possible that either his assumed method to reconcile the gap between individual and social ethics, or the reason that he does not see any gap in the first place, derives from his own background, namely his affiliation with the Boutchichi tariqa. This, however, raises the question of how much his project of ethics for modernity relies on social functions of Sufism that may have survived into modernity better in certain countries, like Morocco, than in others (see the discussion in Van Bruinessen 2009, 134136).

As an extremely prolific writer, Abderrahmane has himself been more active in building upon his ethical work than any other thinker. Nonetheless, it is useful to highlight those who have sought to utilise his analysis of the contemporary world in interesting ways. Wael Hallaq positively cited Taha Abderrahmane in The Impossible State and Restating Orientalism. His interest in Abderrahmane's philosophy is centred on his critique of the ethical failure of modernity, as it supports his argument that ethics was the central domain of Muslim civilisation and is incompatible with the modern nation state (Hallaq 2013, 12, 175 n. 49; Hallaq 2018, 74, 290 n. 15). He further engages with Abderrahmane's ethics in his forthcoming work Reforming Modernity (Hallaq 2019). Mohammed Hashas takes a different approach to the reception of Abderrahmane, using his ideas as a framework to examine what he calls "voices of European Islam." In the section of his book most pertinent to the current study, he discusses how three of four identified thinkers line up with Abderrahmane's idea of reading the Qur'an historically without historicising it: Tariq Ramadan, Tareq Oubrou, and Abdennour Bidar (the exception is Bassam Tibi) (Hashas 2018, 197). Hashas argues that, in general and leaving aside the differences between the studied "voices", the work of these figures is consonant with Abderrahmane's approach in three ways. First, they treat the lifetime of the 
Prophet Muhammad as exemplary for matching the ideals of revelation to his particular society. This implies his second point which is the prioritisation of ethical values over the outward forms of law and the possibility of legal change. Finally, this approach makes the intent of revelation, at this level of analysis, benefit of the world in terms of social justice and public good without thereby stripping it of its metaphysical connection to the divine (Hashas 2018, 198-199). It is interesting to add that each of these points is held in common with Fazlur Rahman.

The second movement of Fazlur Rahman's theory provides the framework for his attempt to read the Qur'an as speaking with its ethical values to the present age. Just as his first movement requires a holistic appreciation of the Qur'an as a text within its socio-historical context, the second one needs a complete view of the contemporary situation. This calls for the "instrumentality" of the social scientist, but the "effective orientation" and "ethical engineering" of the ethicist (Rahman 1982, 7). As these phrases indicate, Fazlur Rahman adopts modern technical language as his chosen metaphor. He places himself within a tradition of Muslim modernism from the middle of the nineteenth century, which he credits as follows:

It was the Muslim Modernist, not the fundamentalist or the traditionalist, then, who recovered the integral Islamic legacy of the earliest days, and, having adopted certain key modern Western institutions and integrated them with Islam as being Islamic par excellence, offered Islam as a successful substitute for and the only viable alternative to the secular West as this Secularism began to show grave cracks in its moral and human structure.

RAHMAN 1980, 243

Despite these achievements, Fazlur Rahman critiques the modernists for failing to apply the ethical vision of Islam comprehensively enough and for relying too heavily on a Western model that provoked a severe reaction from a resurgent conservatism (Rahman 1980, 244). His own project is not an unnuanced embrace of the modern world, but an attempt at an ongoing process of synthesis that he refers to as neo-modernism (Rahman 1980, 246; Bektovic 2016, 170).

In his ethical thought, Fazlur Rahman combines confidence in the discoverability, universality and applicability of extrahistorical Quranic values to the present with full acceptance of the social changes that the modern world brings to Muslim societies and the necessity of religious rules undergoing modification as a result. While Abderrahmane seeks the right of Arab and Muslim 
exceptionalism from modernity as a Western-driven construct, Fazlur Rahman - who fled from the critique of traditionalist ' ulama $\bar{a}^{\prime}$ in Pakistan to settle in the West-sees potential in reading the Islamic scripture with Western universal reason (Bektovic 2016, 160-161). This does leave him open to the critique that, in the search for definite and objective values, he ultimately abandons the multivariate diversity of interpretation within the Muslim tradition, which returns philosophically to his choice to favour Betti ahead of Gadamer (see Moosa 2000, 21).

Fazlur Rahman is aware of the controversial nature of his ideas in the light of prevailing Muslim understandings of the finality of the law and the eternal nature of God's speech. On this point, he distinguishes between the moral and legal planes and argues that the latter can change with the passing of time, as it is "a transaction between the eternity of the Word and the actual ecological situation of seventh-century Arabia" (Rahman 1970, 331). Importantly, the alteration in society that Fazlur Rahman thinks provokes a change in law is not just one of material conditions but can include a shift in cultural values that, as opposed to Qur'anic moral values, are historically bound (Rahman 1970, 330).

The difficulty that Fazlur Rahman, or any modern thinker, finds in contending that certain provisions from the Qur'an for social matters are not permanent is that this very position cannot be found within the text (Koç 2012, 17). Fazlur Rahman implicitly addresses this by widening his historical lens slightly with a concept of the "living Sunna", especially through examples of the reforms of the second caliph 'Umar b. al-Khațtāb (d. 23/644). These occurred during a period in which the nascent Muslim society experienced rapid upheaval due to its expansion into newly conquered lands and an influx of new community members. For Fazlur Rahman, this initial period of change is the closest parallel that modern Muslims have to understand how to adapt the provisions of scripture to their social reality (Rahman 1963, 205-207).

As is the case for his proposal to develop a moral theory from the Quran, Fazlur Rahman does not provide a concrete method for systematically analysing the contemporary world (Moosa 2000, 24). Instead, he discusses various questions in an ad-hoc fashion to illustrate his general approach. His remarks, often concerning the encounter with modernity in Pakistan-the Muslimmajority country he knew best-showcase his incisive mind and characteristic blend of idealism and pragmatism. An example is his discussion of zakatt, in which he argues that the inflexibility of traditionalist ulema contributes to the rise of secular solutions to modern welfare needs:

The Qur'ān, in order to fulfil its fundamental objective of social and economic justice, had ordered the levying of a tax known as zakāh. From the 
uses, enumerated by the Qur'àn, of the expenditure of this tax, it is evident that it was a social welfare tax in the widest possible meaning of "welfare." Further, this was the only tax levied by the Qurān. Now, the Prophet had fixed a certain rate, which leads one to believe that, for the normal needs of that society, he must have judged this rate adequate. The needs of a modern society, however, have expanded immensely. Education, communications and other developmental schemes are now considered to be among the necessities of modern welfare. This would, therefore, argue for a readjustment of the rate of $z a k a \bar{h}$ tax to modern needs. The Ulama', however, forbid any change in the rate of zakāh and assert that if $z a k \bar{a} h$ is inadequate to meet the larger welfare needs of the Muslim society, then Muslim Governments can levy other taxes. It is at this critical juncture that the administrator tells the Ulama, "You say that here is only one Islamic tax which is zakāh. When this proves inadequate, you forbid any change in the zakāh-rate but you say that I can levy other taxes. You are, thereby, introducing a dualism which I find unworkable. If I can levy other taxes, I shall levy them and fulfil the needs of my society and your zakāh is superfluous." This is the essence of secularism.

RAHMAN 1966, 119

Although Fazlur Rahman argued forcefully and consistently for legal reform based on a holistic approach to Quranic ethics and a critical appraisal of the social needs of Muslim societies, he developed through personal experience an awareness of the difficulty of getting a hearing for his ideas. Looking back on his suggested changes to the rules of $z a k \bar{a} t$ in Pakistan, he noted that he not only received opposition from the 'ulama $\bar{a}$ ' for his advocacy of a shift from established legal views but from modernists for his comprehensive, rather than piecemeal, solution (Rahman 1970, 328). He recognised that the prospects for the popular acceptance of his approach were bleak and saw that, rather than adopting neo-modernism, the failures of modernism in the Muslim world would push the populations towards both conservatism and secularism (Rahman 1970, 331).

Such secularism, however, is not necessarily the end of the story. Fazlur Rahman gave the example of Turkey as a secularised Muslim country that, through a strong attachment to Islam, may be able to infuse an Islamic ethos within its secular structures (Rahman 1970, 332-333). The recent rise of ilahiyat (theological) faculties in Turkey and their blend of Islamic values and modern administration may indicate Fazlur Rahman's prescience in this observation (see Pacaci and Aktay 2006, 140).

It is interesting to note that some of the most important work done to extend Fazlur Rahman's ethical thought has taken place in Turkey. Prominent among 
this are members of the "Ankara School", so called because of their association with the theological faculty of Ankara University. Adil Çiftçi, a graduate of the university, has translated works of Fazlur Rahman into Turkish, and worked to extend the method of his ethical framework (Körner 2005, 109). He comments that Fazlur Rahman's first movement is inductive, while his second one is deductive, which qualifies it as scientific (Körner 2005, 125; see Rahman 1979, 221); he supplies additional criteria for checking that the ethical principles extracted are correct (Körner 2005, 125); and he overcomes the arguably static nature of Fazlur Rahman's engagement with the Qur'an by invoking the hermeneutic circle, in which each engagement with the text provokes new questions that require new responses (Körner 2005, 124). On the other hand, he seems to uncritically side with Fazlur Rahman's interpretation of Betti against Gadamer and does not seriously address the shortcomings within his predecessor's theory (Körner 2005, 130, 133).

A second member of the Ankara School is Mehmet Paçaci who completed his doctorate at Ankara University and subsequently became a professor in the theological faculty. He makes a more significant break from Fazlur Rahman's theory than Çiftçi by fully adopting the hermeneutic circle of Gadamer and acknowledging that every interpretation takes place within the framework of the interpreter's pre-existing situation and concerns (Körner 2006, 808). This perspective allows him to raise the same existential question of the gap between the contemporary reader and revealed text with which I began this study. Furthermore, somewhat like Abderrahmane, he interrogates the power relations that contribute to the difficulty of bringing the Qur'anic text into the present world: Western hegemony makes Muslims the objects, and not agents, of history (Körner 2005, 76). While diagnosing the fear that holds many back from contemplating a new synthesis of Islam and modernity along the lines that Fazlur Rahman proposes, Paçaci rejects it as a mistake. His adaptation of Gadamer lets him propose that Qur'anic interpretation must start from the living Muslim interpreter in history, no matter how difficult their circumstances may seem (Körner 2005, 77; Körner 2006, 808).

Within English-language scholarship, an important reception of Fazlur Rahman's ethical ideas can be found in the work of the Australian-based academic Abdullah Saeed. He draws from Fazlur Rahman's theoretical ideas as a major source for his project of contextual interpretation, or contextualism, as he calls it (Saeed 2006, 24-25; Saeed 2014, 23). Saeed develops Fazlur Rahman's participative theology of revelation into a four-level model, of which his fourth (and final) level is most relevant to the present study. It refers to a continuing stage of revelation after the closing of the Qur'anic text in which, guided by God, the Muslim community continues to add through praxis to a common store 
of wisdom (Saeed 2006, 41). In effect, he here unifies Fazlur Rahman's ideas of prophetic revelation and the living Sunna into a single schema. A similar interest in systemisation is apparent in Saeed's four-stage model of Qur'anic interpretation (Saeed 2006, 150) and his discussion of a hierarchy of Quranic values: obligatory, fundamental, protectional, implementational and instructional, which exist in a continuum of greater to lesser universality (Saeed 2006, 130-143). Though the former model is basically a restatement of Fazlur Rahman's double movement theory, the latter is genuinely interesting as it amounts to an attempt to move beyond ad-hoc discussion of individual values towards a normative theory, though it does share some notable similarities with discourses of maqūṣid al-sharīa.

As a point of comparison, I have outlined a specific hierarchy for the important Quranic value of societal justice (qist), consisting of political, distributive and corrective spheres, followed by subjects, topics, principles and rulings in each, which correlates to the thematic structure of my book (Harvey 2018, 43). I have also attempted a more comprehensive and unitary extraction and classification of ethical values within each sphere, such as discussing principles of just governance in the sphere of political justice. However, so far, I have not attempted to perform an equivalent to Fazlur Rahman's second movement of application to the contemporary world.

\section{Conclusion}

A succinct overview of the continuities and divergences between the thought of Taha Abderrahmane and Fazlur Rahman in the chosen area of study remains useful as a way of closure. Both thinkers conceptualise values as abstract extrahistorical entities that must be sought within the Quranic discourse and then realised in each time period. They agree that the ethical dimension of the revelation is more central than the legal and must take priority. Each emphasises that these ethics can only be understood when intimately related to the contextual situation of the historical society led by the Prophet Muhammad. Finally, they share an inclination to adapt existing models of legal theory for their respective renewal projects while remaining open to radical reinterpretation of these earlier models.

The two also have some significant differences. Theoretically, Abderrahmane seems to highlight the ethical role of the Qur'an as the final revealed dispensation to humanity more than Fazlur Rahman. He also focuses on personal, or virtue, ethics ahead of those pertaining to the social sphere, while Fazlur Rahman has the opposite tendency. This ties into their differing recep- 
tions of Sufism and its place within Muslim ethical thought. Abderrahmane, himself a member of the Boutchichi țariqa, puts Sufi ethics at the heart of his philosophy of the trusteeship paradigm. Fazlur Rahman, while recognising the importance of the spiritual dimension in Islam, is extremely critical of any substitution of Sufi practices for social ethics, as well as what he sees as ecstatic and superstitious excesses, especially those of later Sufism (Rahman 1962, 19-22). The last identified point of contrast is that Fazlur Rahman has a greater inclination than Abderrahmane to illustrate his theoretical ideas with specific applied examples of Qur'anic legislation and ethics, though he still often provides only a summary treatment, stopping short of carrying out his first movement systematically.

In looking at modernity, the central position that each thinker gives to Islamic ethical renewal demonstrates the closeness of their ideas, as does their convergence on the three points identified by Hashas: the exemplary nature of the initial period of revelation for recovering values, the priority of the ethical over the legal aspect of Quranic rulings, and that they must benefit people in this world without being desacralised. However, here too there is a notable divergence over their stance towards modernity in its current Westerndominated form. In works written in the twenty-first century, Abderrahmane seeks to realise what he calls the spirit of modernity in a new ethical formulation enriched by connection to the divine through the Qur'an. Fazlur Rahman, a pragmatically inclined twentieth-century thinker more at ease with the idea of enlightenment universal reason, looks instead towards a neo-modernist synthesis between the existing framework of modernity and Islamic ethics.

The work of contemporary Muslim ethical thinkers who have built upon the ideas of Taha Abderrahmane and Fazlur Rahman demonstrates that further constructive development and reconciliation between their positions is very possible. In the case of Fazlur Rahman, whose ideas have had a longer period of time to be absorbed, the writings of Çiftçi and Paçaci in Turkish (with the excellent critical commentary of Körner making them accessible to a wider audience), as well as that of Saeed and myself, have already shown how a process of refinement and the overcoming of identified shortcomings can take place in a contemporary Muslim ethical tradition. The same is starting to happen to Abderrahmane with scholars, such as Hashas, Birouk and Hallaq, and will continue to gather pace as his work becomes better known. An obvious direction that could be explored is to combine Abderrahmane's more critical outlook towards the Western form of modernity and his spiritual themes with Fazlur Rahman's focus on social ethics and applied Qur'anic hermeneutics. The preceding discussion indicates that this is likely to be a fruitful endeavour in the aspiration for a meaningful Islamic contribution to an ethical modernity. 


\section{References}

'Abd al-Raḥmān, Ṭāha. 1995. Fiqh al-Falsafa ı: al-Falsafa wa-l-Tarjama. Beirut: al-Markaz al-Thaqāfì al-'Arabī.

'Abd al-Raḥmān, Ṭāha. 200o. Su’āl al-Akhlāq: Musāhama fì al-Naqd al-Akhlāqī lilHadātha al-Gharbiyya. Beirut: al-Markaz al-Thaqāfī al-'Arabī.

'Abd al-Raḥmān, Ṭāha. 20o6. Rūḥ al-Hadātha: al-Madkhal ilā Ta’siss al-Hadātha alIslāmiyya. Beirut: al-Markaz al-Thaqāfî al-'Arabī.

Abderrahmane, Taha. 2008a. "A Global Ethic: Its Scope and Limits." Tabah Papers Series 1: 1-19.

Abderrahmane, Taha. 2008b. "Renewing Religious Thought in Islam: Prerequisites and Impediments." Islam Today 25: 87-100.

'Abd al-Raḥmān, Țāha. 2011. Hiwārāt min Ajl al-Mustaqbal. Beirut: al-Shabaka al-Arabiyya lil-Abhāth wa-l-Nashr.

'Abd al-Raḥmān, Ṭāha. 2014a. Bu's al-Dahrāniyya: al-Naqd al-I'timānī li-Faṣl al-Akhlāq 'an al-Dīn. Beirut: al-Shabaka al-'Arabiyya lil-Abhāth wa-l-Nashr.

Abderrahmane, Taha. 2014b. "The Globalization of the Economy and the Crisis of Values." Islam Today 30: 111-128.

'Abd al-Raḥmān, Țāha. 2015. Su'āl al-Manhaj: Fı̄ Ufuq al-Ta’sīs li-Unmūdhaj Fikrī Jadìd, Beirut: al-Mu'assasa al-'Arabiyya lil-Fikr wa-l-Ibdāc.

Ahmed, Ahad M. 2012. "The Theological Thought of Fazlur Rahman: A Modern Mutakallim." M.Phil. thesis, International Islamic University, Islamabad.

Bektovic, Safet. 2016. "Towards a Neo-Modernist Islam: Fazlur Rahman and the Rethinking of Islamic Tradition and Modernity." Studia Theologica-Nordic Journal of Theology 70 (2): 16o-178.

Bevers, Michael. 2018. Islam, Globalization and Modernity: Approaching Global Ethics Through the Works of Taha Abderrahmane. PhD dissertation, Indiana University.

Birouk, Monir. 2017. “Taha Abderrahmane's Ethics of Ihsan: A Lopsided Conception of Justice and Citizenship in the Post-Arab Spring." Paper, The International Institute of Islamic Thought, Herndon, vA, July 27.

Bū Zabra, 'Abd al-Salām. 2011. Tạha 'Abd al-Raḥmān wa-Naqd al-Hadātha. Beirut: Jadāwil.

Caputo, John D. 2018. Hermeneutics: Facts and Interpretation in the Age of Information. London: Penguin.

El-Affendi, Abdelwahab. 20og. "The People on the Edge: Religious Reform and the Burden of the Western Muslim Intellectual." Harvard Middle Eastern and Islamic Review 8: $19-5$ o.

Gadamer, Hans-Georg. 2013. Truth and Method. Trans. Joel Weinsheimer and Donald G. Marshall. London: Bloomsbury. 
Hallaq, Wael B. 2013. The Impossible State: Islam, Politics, and Modernity's Moral Predicament. New York: Columbia University Press.

Hallaq, Wael B. 2018. Restating Orientalism: A Critique of Modern Knowledge. New York: Columbia University Press.

Hallaq, Wael B. 2019. Reforming Modernity: Ethics and the New Human in the Philosophy of Abdurrahman Taha. New York: Columbia University Press.

Harvey, Ramon. 2018. The Qur'an and the Just Society. Edinburgh: Edinburgh University Press.

Hashas, Mohammed. 2015. “Taha Abderrahmane's Trusteeship Paradigm: Spiritual Modernity and the Islamic Contribution to the Formation of a Renewed Universal Civilization of Ethos." Oriente Moderno 95: 67-105.

Hashas, Mohammed. 2019. The Idea of European Islam: Religion, Ethics, Politics and Perpetual Modernity. London and New York: Routledge.

Koç, Mehmet Akif. 2012. "The Influence of Western Qur’anic Scholarship in Turkey." Journal of Qur'anic Studies 14 (1): 9-44.

Körner, Felix. 2005. Revisionist Koran Hermeneutics in Contemporary Turkish University Theology: Rethinking Islam. Würzburg: Ergon Verlag.

Körner, Felix. 20o6. “Turkish Theology Meets European Philosophy: Emilio Betti, HansGeorg Gadamer and Paul Ricoeur in Muslim Thinking." Revista Portuguesa de Filosofia 62 (2): 805-809.

Koshul, Basit T. 1994. “Fazlur Rahman's 'Islam and Modernity’ Revisited." Islamic Studies $33(4): 403-417$.

Mashrūḥ, Ibrāhīm. 2009. Țāha 'Abd al-Raḥmān: Qirā’a fì Mashrūih al-Fikrī. Beirut: Markaz al-Ḥậ̄āra li-Tanmiyat al-Fikr al-Islāmī.

Moosa, Ebrahim. 200o. Introduction to Revival and Reform in Islam: A Study of Islamic Fundamentalism, by Fazlur Rahman. Oxford: Oneworld.

Moosa, Ebrahim. 2014. “On Reading Shāṭibī in Rabat and Tunis." In Adis Duderija (ed). Maqasid Al Shari'a and Contemporary Reformist Muslim Thought: An Examination. New York: Palgrave Macmillan.

Pacaci, Mehmet, and Yasin Aktay. 2006. "75 Years of Higher Religious Education in Modern Turkey." In Ibrahim M. Abu-Rabic (ed). The Blackwell Companion to Contemporary Islamic Thought. Oxford: Blackwell.

Rahman, Fazlur. 1962. "The Post-Formative Developments in Islam." Islamic Studies 1 (4): 1-23.

Rahman, Fazlur. 1963. "Social Change and Early Sunnah." Islamic Studies 2 (2): 205-216. Rahman, Fazlur. 1964. "Ribā and Interest." Islamic Studies 3 (1): 1-43.

Rahman, Fazlur. 1965. "The Concept of Hadd in Islamic Law." Islamic Law 4 (3): 237-251. Rahman, Fazlur. 1970. "Islamic Modernism: Its Scope, Method and Alternatives." International Journal of Middle East Studies 1: 317-333.

Rahman, Fazlur. 1971. "Functional Interdependence of Law and Theology." In Theology 
and Law in Islam, edited by Gustave E. von Grunebaum. Wiesbaden: Harrassowitz Verlag.

Rahman, Fazlur. 1976. Islam. 2nd ed. Chicago: University of Chicago Press.

Rahman, Fazlur. 1979. "Towards Reformulating the Methodology of Islamic Law: Sheikh Yamani on 'Public Interest' in Islamic Law." New York University Journal of International Law and Politics 12: 219-224.

Rahman, Fazlur. 1980a. "A Survey of Modernization of Muslim Family Law." International Journal of Middle East Studies 11 (4): 451-465.

Rahman, Fazlur. 198ob. "Islam: Legacy and Contemporary Challenge." Islamic Studies 19 (4): $235^{-246 .}$

Rahman, Fazlur. 1981. "A Recent Controversy over the Interpretation of Shürā." History of Religions 20 (4): 291-301.

Rahman, Fazlur. 1982. Islam and Modernity: Transformation of an Intellectual Tradition. Chicago: University of Chicago Press.

Rahman, Fazlur. 1983. "Some Key Ethical Concepts of the Qur'ān." The Journal of Religious Ethics 11 (2): 170-185.

Saeed, Abdullah. 2006. Interpreting the Qur'an: Towards a Contemporary Approach. New York: Routledge.

Saeed, Abdullah. 2014. Reading the Qur'an in the Twenty-First Century: A Contextualist Approach. Abingdon: Routledge.

Sommer, Benjamin D. 2015. Revelation and Authority: Sinai in Jewish Scripture and Tradition. New Haven, ст: Yale University Press.

Van Bruinessen, Martin. 20o9. "Sufism, 'Popular' Islam and the Encounter with Modernity." In Muhammad Khalid Masud, Armando Salvatore and Martin van Bruinessen (eds). Islam and Modernity: Key Issues and Debates. Edinburgh: Edinburgh University Press. 